\title{
Performance of Oilseed Sunflower Cultivars in an Oxisol in Northwestern Puerto Rico ${ }^{1,2}$
}

\author{
M. A. Lugo-López, J. Badillo-Feliciano, and L. Calduch ${ }^{3}$
}

\begin{abstract}
Oil yield potential of five high yielding sunflower cultivars grown under tropical conditions in an Oxisol in northwestern Puerto Rico was evaluated. No significant yield differences were measured with cultivars Sputnik, Peredovik, Hybrid 891, Hybrid 894, and Hybrid 896. In spite of this fact, a fieldwide average of $1616 \mathrm{~kg} / \mathrm{ha}$ was obtained. Yields of this magnitude are considered rather high for oilseed sunflowers under a tropical environment. The key to successful sunflower production in the deep, well-drained, acid, and relatively infertile soils of the tropics seems to lie in the use of high yielding cultivars coupled with rational fertilization and sound crop and soil management practices.
\end{abstract}

\section{INTRODUCTION}

Sunflower (Helianthus annuus) is an important source of food, second only to soybeans as an oilseed crop. ${ }^{4}$ The kernels contain about $50 \%$ oil. Sunflowers are usually grown commercially in temperate climates but are also grown in the tropics and subtropics. They are tolerant to heat and drought, respond to sunny weather, and are adaptable to a wide range of soil conditions. However, sunflower seed yields are high in temperate zones, sometimes over $2,000 \mathrm{~kg} / \mathrm{ha}$, while they are as low as $350 \mathrm{~kg} / \mathrm{ha}$ in some tropical areas. ${ }^{5}$

Sunflower seeds are high in protein (20 to 24\%) and can be processed for oil extraction or eaten as salted whole seeds or dehulled roasted nuts. The oil is used for cooking, fuel, and for preparing margarine and other foods. The byproducts from oil processing are an excellent feed for ruminants. The protein is equal to soybean protein in digestibility and biological value. Sunflower seeds are high in $\mathrm{Ca}, \mathrm{P}$, and $\mathrm{Fe}$ as well as thiamin, riboflavin, and niacin.

1 Manuscript submitted to Editorial Board June 17, 1976.

${ }^{2}$ Joint contribution from the Department of Agronomy, Cornell University, Ithaca, N.Y., and the Agricultural Experiment Station, University of Puerto Rico, Mayagüez Campus, Rio Piedras, P.R. This study was part of the investigations supported by USAID under research contract ta-c-1104 entitled: "Soil Fertility in the Humid Tropics."

${ }^{3}$ Professor and Soil Scientist, Associate Agronomist and Research Assistant, respectively, Agricultural Experiment Station, University of Puerto Rico, Mayagüez Campus, Rio Piedras, P.R.

${ }^{4}$ There are two distinct classes of cultivated sunflowers: oilseed and confectionary or garden class. Cultivars in the oilseed class are used exclusively for oil extraction; confectionary varieties are used primarily for salting or roasting.

${ }^{5}$ Litzenberger, S. C. (ed.) Guide for field crops in the tropies and subtropics, Agency Int. Develop., p. 194-202, Washington, D.C., 1974. 
The potential of this crop under tropical conditions offers distinct possibilities of production both for food and for industrial purposes in the deep, well-drained, acid, and relatively infertile soils of the humid tropics. This paper reports on a preliminary evaluation of high yielding cultivars grown in an Oxisol using a technology of production comparable to that used in temperate zones.

\section{MATERIALS AND METHODS}

An experiment to evaluate the performance of five high yielding cultivars was established at the Isabela Substation farm in northwestern Puerto Rico. The climate is maritime humid tropical. Mean annual rainfall is about $1658 \mathrm{~mm}$. Evaporation from a Class A pan is approximately $6 \mathrm{~mm}$ /day during the summer and $4 \mathrm{~mm}$ /day during the winter. The mean annual maximum temperature is $29.4^{\circ} \mathrm{C}$ while the mean minimum temperature is $18.9^{\circ} \mathrm{C}$. Solar radiation ranges from an average of 300 langleys/day in the winter to 600 langleys/day in the summer. The elevation is about $122 \mathrm{~m}$ above mean sea level.

The soil is classified as Coto, a Tropeptic Haplorthox, clayey, kaolinitic, isohyperthermic. It has an exchange capacity of around 13 meq and $25 \% \mathrm{Ca}$ saturation. It is high in $\mathrm{Mn}$, low in $\mathrm{P}$, and has a $\mathrm{pH}$ of 4.8.

The experiment followed a complete block design with five treatments (cultivars) replicated six times. Plots were $3.7 \times 0.91 \mathrm{~m}$ with $0.76 \mathrm{~m}$ alleys between plots. The cultivars tested were Hybrid 894, Hybrid 896, and Hybrid 891, supplied by ARS, USDA, and the Russian varieties Sputnik and Peredovik. Seed was sown on October 2, 1975, and the heads were harvested on January 28, 1976.

The crop received a 10-10-10 fertilizer at the rate of $1345 \mathrm{~kg} / \mathrm{ha}$ on November 6, some 34 days after planting. Crop protection was provided by six sprayings of Lannate ${ }^{6}$ at the rate of $2.47 \mathrm{qt} / \mathrm{ha}+$ Dithane M- 45 at the rate of $10.9 \mathrm{~kg} / \mathrm{ha}$. Supplemental irrigation was applied four times during the crop cycle.

Data were taken on germination, plant height, number of heads harvested, and seed yield when the plants were 89 days old. Data were analyzed statistically.

\section{RESULTS AND DISCUSSION}

Data on germination, plant height, number of heads harvested, and weight of whole seeds of the five varieties are given in table 1. Mean differences were not significant, except in plant height. Plants from

\footnotetext{
${ }^{6}$ Trade names are used in this publication solely for the purpose of providing specific information. Mention of a trade name does not constitute a guarantee or warranty by the Agricultural Experiment Station of the University of Puerto Rico or an endorsement over other materials not mentioned.
} 
cultivar Sputnik were significantly taller than those from Hybrid 894 and Hybrid 896. A field-wide average of $1616 \mathrm{~kg} / \mathrm{ha}$, considered rather high for a tropical environment, was obtained. Thus, all these cultivars performed rather well under the experimental conditions that prevailed during the crop cycle. The potential of high yielding cultivars under tropical conditions when properly managed, and using a technology comparable to that used in temperate regions was thus shown.

Plant growth was excellent in all cases. The crop did not suffer any damage attributable to insect and disease pests. The technological package of practices used was the same as in the Southern United States, including the use of porous, well-drained soils, fertilization with banded N-P-K, irrigation to supplement rainfall, weed control, and preventive pest control. It seems that under such conditions, oilseed sunflower production is possible in tropical environments even in acid, relatively infertile soils such as Oxisols.

TABLE 1. -Germination, plant height, number of heads harvested, and seed yield of five oilseed sunflower cultivars grown in an Oxisol, Puerto Rico

\begin{tabular}{lcccc}
\hline \multicolumn{1}{c}{ Cultivar } & Germination & Plant height & Heads harvested & Seed yield \\
\hline & No. of plants & $C m$ & No./plot & Kg/ha \\
Sputnik & $17.5 \mathrm{a}^{1}$ & $152.4 \mathrm{a}$ & $17.2 \mathrm{a}$ & $1774 \mathrm{a}$ \\
Peredovik & $17.5 \mathrm{a}$ & $145.8 \mathrm{ab}$ & $17.0 \mathrm{a}$ & $1695 \mathrm{a}$ \\
Hybrid 891 & $18.7 \mathrm{a}$ & $141.9 \mathrm{ab}$ & $18.3 \mathrm{a}$ & $1669 \mathrm{a}$ \\
Hybrid 894 & $18.0 \mathrm{a}$ & $140.5 \mathrm{~b}$ & $17.3 \mathrm{a}$ & $1518 \mathrm{a}$ \\
Hybrid 896 & $16.0 \mathrm{a}$ & $137.7 \mathrm{~b}$ & $15.7 \mathrm{a}$ & $1423 \mathrm{a}$ \\
\hline
\end{tabular}

${ }^{1}$ Means in a column with one or more letters in common do not differ significantly at the $5 \%$ probability level.

This crop is not particularly sensitive to changes in day length, making it suitable to tropical areas. In addition, vast tracts of land in the humid tropics offer a good potential for the production of this valuable crop. Oxisols seem particularly well suited for sunflower production, but the use of $\mathrm{N}$ fertilizers is particularly important in these soils.

Sunflowers require moist and mellow beds and removal of weeds at an early stage to reduce to a minimum the competition for nutrients and moisture.

The results herein reported should serve as a stimulus for further research work on this valuable food and industrial crop. It appears that research concerning the development of varieties specifically for tropical conditions as well as the development of management practices should merit a high priority. The fact that sunflowers can be utilized effectively for subsistence or as a cash crop with industrial possibilities further points to the need for more research on the production of this crop under tropical environments. 


\section{RESUMEN}

El comportamiento de cinco cultivares de girasol, especialmente desarrollados para la producción de aceite, se evaluó bajo condiciones tropicales en un Oxisol en el noroeste de Puerto Rico. No se obtuvieron diferencias significativas en rendimiento entre los cultivares Sputnik, Peredovik, Hybrid 891, Hybrid 894 y Hybrid 896. Sin embargo, se obtuvo un rendimiento medio de $1616 \mathrm{~kg}$./ha. Rendimientos de semilla de girasol de esta magnitud se consideran bastante buenos en ambientes tropicales. La clave para el éxito en la producción rentable de girasol en los suelos profundos, de buen desagüe, ácidos y relativamente infértiles de los trópicos parece que radica en la selección de cultivares de alto potencial productivo conjuntamente con un sistema de abonamiento racional y prácticas mejoradas de cultivo. 